\title{
Editorials
}

\section{The contribution of epidemiology to defining the most appropriate approach to genetic research on schizophrenia}

\author{
SARAH TOSATO and ANTONIO LASALVIA
}

\begin{abstract}
Psychosis is thought to have a strong genetic component, but many efforts to discover the underlying putative schizophrenia genes have yielded disappointing results. In fact, no strong associations emerged in the first genome-wide association studies in psychiatry and weakly observed associations were not related to the candidate genes identified in previous studies. These partially successful findings may be explained by the fact that genetic research in psychiatry suffers from confounding issues related to phenotype definition, the considerable degree of phenotypic variability and diagnostic uncertainty, absence of specific neuropathological features and environmental influences. To make progress it is first necessary to deconstruct psychosis based on symptomatology, and then to correlate particular phenotypes with genetic variants. Moreover, it is time to conduct studies that define persistent aspects of the schizophrenic profile that are more likely to represent an underlying biological pathogenesis, as opposed to fluctuating symptoms that are possibly environmentally mediated. In fact, progress in understanding the etiology of schizophrenia will depend upon the availability of good measures of genetic liability as well as relevant environmental exposures during critical periods of an individual's life. If environmental and/or genetic factors are not precisely measured, it is impossible to study their independent effects or interactions.
\end{abstract}

Declaration of Interest: None.

\section{INTRODUCTION}

Twin and adoption studies (Cardno et al., 1999) have established that schizophrenia has a strong genetic component. Schizophrenia is a complex genetic disorder consisting of multiple genes which exert small effects. Although the heritability of schizophrenia is approximately 80\% (Cardno \& Gottesman, 2000; Sullivan et al., 2003) and many efforts to discover the underlying putative schizophrenia genes have been made, no specific susceptibility gene has been clearly identified.

During the last two decades, two complementary approaches have been used in the search for susceptibility genes: linkage studies, which do not rely on specific biological hypotheses but seek to identify chromosomal

Address for correspondence: Dr. S. Tosato, Department of Medicine and Public Health, Section of Psychiatry and Clinical Psychology, Policlinico G.B. Rossi, P.le L.A. Scuro 10, 37134 Verona (Italy).

Fax: +39-045-8027498

E-mail: sarah.tosato@univr.it regions containing susceptibility loci; and association studies, which are sensitive enough to detect small gene effects, but have to rely on plausible candidate genes (Norton et al., 2006; Owen et al., 2007). More recently, two major developments contributed to the transformation of prospects for searching for genes involved in complex trait disorders:

1) the HapMap project (http://www.hapmap.org/) has permitted a better knowledge of the patterns of the genome sequence landscape and variation in human populations, and

2) the rapid advances in genotyping capabilities makes it possible to assay affordably most genome sequence variations attributable to common single nucleotide polymorphisms (SNPs) and copy number variants (CNVs) (St Clair, 2009; Stefansson et al., 2008).

In spite of these advanced techniques, the results are often disappointing. In fact, the first genome-wide association studies in schizophrenia and bipolar disorder produced no strong findings and weakly observed 
associations were not related to candidate genes identified in previous studies. Moreover, no consistent results were replicated by different studies (Crow, 2008). Until now a thousand association studies involving 700 candidate genes (Allen et al., 2008) supported the role of some genes, including Neuregulin 1 (NRG1), dysbindin (DTNBP1), dopamine receptors D1-4 (DRD1-4) and Disrupted-in-Schizophrenia-1 (DISC1) in inducing vulnerability to schizophrenia. However, even for these "promising genes", there is a remarkable failure to replicate exactly the same markers and haplotypes across studies and a lack of consistency in implicating particular alleles in the development of schizophrenia (Alkelai et al., 2008; Sanders et al., 2008; Sullivan, 2008). Consequently, it appears that the identification of polymorphisms for psychiatric disorders is more difficult than for other complex trait disorders such as cardiovascular diseases, diabetes or cancer (Welcome Trust Case Control Consortium, 2007).

In spite of this, the advantages in genome scanning technology and the discovery of an association of CNVs with autism and schizophrenia (Walsh et al., 2008; Weiss et al., 2008) have raised a number of fascinating new clinical questions concerning the phenotypic boundaries among major neuropsychiatric disorders, the genetic and environmental factors that influence phenotype and the relationship between behavior and genomic evolution.

\section{THE CLINICAL HETEROGENEITY OF THE “PHENOTYPE” DEFINITION}

The inconsistent results and disappointing findings of genetic research into schizophrenia may be due to the intrinsic characteristics of the phenotype under investigation: the "diagnosis of schizophrenia". Its manifest clinical heterogeneity, combined with a failure, to date, to demonstrate the existence of a unitary disease process, has led to the conceptualization of schizophrenia as a heterogeneous disorder. Many efforts have been made to link levels of heterogeneity, particularly between pathophysiology and phenomenology. However, the extent to which the clinical, pathophysiological and etiological components are interrelated is still largely unknown. Progress in understanding the disorder may have been hampered by the heterogeneous groups - at clinical, etiological and pathological levels - of patients whom researchers have studied under the name of "schizophrenia" (Peralta \& Cuesta, 2003).
The heterogeneity issue in schizophrenia is reflected by the term 'schizophrenias' coined by Bleuler (1911) to describe the complex phenomenological picture at the clinical level. Symptoms of schizophrenia affect multiple psychological domains, including perception, inferential thinking, language, attention, social interaction, emotional expression, and volition. While the description of symptoms and signs of schizophrenia has remained mainly unchanged over the years, the way in which authors have articulated the varied phenomenological manifestations has been very unequal, thus rendering different views of schizophrenia across periods and countries. During the last forty years, psychopathologists have tried to simplify this complex array of symptoms and signs in several ways. Firstly, the concept of positive and negative symptoms has been developed in an attempt to integrate the various aspects (symptoms, pathophysiology and outcome) of schizophrenia (Strauss et al., 1974; Andreasen \& Olsen, 1982). Subsequently, a 3 -factor model was proposed by Liddle (1987), including positive, negative and disorganised dimensions, which has since been confirmed through several factor analytic studies (Lenzenweger et al., 1991; Malla et al., 1993; Andreasen et al., 1994). In recent years more complex multidimensional models have been reported: a four-syndrome model based on the dimensions of psychosis, disorganization, negative and social dysfunction has been proposed (Peralta et al., 1994; Dollfus \& Everitt, 1998). Kay \& Sevy (1990), suggest seven dimensions, although the consensus at this point is that just five factors, positive, negative, depressive, disorganization, and excitement, are the ones that best represent the scale's factor structure (Lindenmayer et al., 1994). In conclusion, there is still little agreement about the number of dimensions necessary for an adequate representation of schizophrenic psychopathology, and views remain largely dependent on the rating scale employed (Peralta \& Cuesta, 2000).

\section{THE TRAJECTORIES OF SCHIZOPHRENIA: THE HETEROGENEITY OF OUTCOME}

Over the last decades research has consistently found that, contrary to kraepelinian dogma, schizophrenia shows considerable heterogeneity in both course and outcome (Hegarty et al., 1994; Davidson \& McGlashan, 1997). A recent review on the long-term outcome of schizophrenia found that between $21 \%$ and $57 \%$ of patients have a good outcome, depending on the outcome dimension and the strictness of the diagnostic criteria used (Jobe \& Harrow, 2005). Some of this heterogeneity

Epidemiologia e Psichiatria Sociale, 18, 2, 2009 
may be due to patient-related factors, such as age of onset, acuteness of onset, and to other factors linked to the severity of the disorder, such as the duration of untreated psychosis, cognition and early treatment response (Emsley et al., 2008).

Long-term follow-up studies have also established heterogeneity in the levels of symptoms and functioning within individuals with schizophrenia as well as across individuals. The earlier work of Strauss \& Carpenter (1977) demonstrates the "loosely linked" nature of the relationships between different outcome dimensions. Building on this work, later research has consistently found that levels of psychopathology, specifically positive symptoms and social functioning, show only weak relationships to each other (Lasalvia et al., 2007a). Indeed, the multiple outcome dimensions in schizophrenia represent an "open-linked system" of outcome, since they all show relatively independent trajectories.

The negative symptom cluster, once established, is more stable over time and is more likely to be associated with neurocognitive impairments (Harvey et al., 2006), brain abnormalities (Shenton et al., 2001) and work and social incapacity (Lysaker \& Bell, 1995; Bowie et al., 2006). Positive symptoms have consistently been found to show an independent pattern of evolution over the course of the disorder (Eaton et al., 1995), with a tendency to a reduction in severity levels over time (Lasalvia et al., 2007a). On the other hand, once established, cognitive deficits, similarly to negative symptoms, are relatively stable over time (Hyde et al., 1994; Mockler et al., 1997; Hijman et al., 2003); in addition they are associated with incapacity to work (Dickinson et al., 2007; Bowie et al., 2008).

The marked heterogeneity in the outcomes of schizophrenia depends on which specific perception of outcome by treating clinicians or patients themselves is considered, and the stringency of defining a good or poor outcome. For instance, in a sample of long-term patients treated in the South-Verona Community-based Mental Health Service, it was found that overall psychopathology (clinician-rated) tend to worsen over time with a clearcut deterioration in negative symptoms, whereas subjective quality of life showed no significant change over the same period (Ruggeri et al., 2004). With regards to clinician-assessed social functioning, a trend towards deterioration was found. The overall number of patient-rated needs for care showed a significant decrease in social and health domains and an increase in functioning needs. These findings lead us to the view that there may be partially overlapping but distinct domains that can be identified as legitimate outcomes for schizophrenia. Such dif- ferent domains may not vary directly. They may be influenced at least partially by separate predictors that may reveal different rates of poor and good outcomes depending upon which we accord primacy. We therefore suggest that, for both mental health care provision and research, staff-rated and patient-rated outcome measures are not interchangeable, but should be separately considered. This opens up lines of scientific enquiry to investigate the heterogeneity of outcomes when measured across multiple dimensions and rated from different perspectives (Ruggeri et al., 2005; Lasalvia et al., 2007b).

\section{CROSSING THE DIAGNOSTIC BOUNDARIES}

Research in the field of genetic psychiatry suffers from confounding issues related to phenotype definition (Craddock et al., 2008), considerable phenotypic variability and diagnostic uncertainty, absence of specific neuropathological features or biomarkers and environmental influences (Kennedy et al., 2003).

One of the main issues is related to the validity of the construct of schizophrenia. Over the decade, the DSM-IV definition of schizophrenia has been the most influential classification in clinical practice and research. Its clear criterion-based definition facilitates diagnostic agreement and communication among practitioners and researchers. However, although the DSM definition of schizophrenia has an undoubtedly high clinical utility, it does not provide information about the fundamental nature of schizophrenia: it does not answer the basic taxonomic question: "Are the correlations of observed clinical characteristics corroborative of underlying latent phenotypic dimensions (continuous distributions), latent categories (composed of one or more class or sub-disorder, each with its own phenotypic presentation) or a mix of the two?" (Meehl, 1995). If our definition of schizophrenia does not represent a "real" construct in nature, then it will not delineate the true pathology and causal mechanisms underlying psychosis; it will obfuscate etiology (Allardyce et al., 2007).

Most of the genetic research into psychoses has been based on the "given" descriptive diagnostic categories of schizophrenia and bipolar disorder, notwithstanding the fact that their validity has been challenged by emerging data from many fields of psychiatric research (Craddock et al., 2006; Murray et al., 2004).

Recent findings provide evidence for an overlap in genetic susceptibility across traditional psychosis categories, which are entirely based on the presence of clinical symptoms with several dimensions. The clearest evidence

Epidemiologia e Psichiatria Sociale, 18, 2, 2009 
was found in the familial co-aggregation of both schizophrenia and bipolar disorder (Baron et al., 1982; Gershon et al., 1988; Maier et al., 1993; 2005; Mortensen et al., 2003). In fact, the monozygotic (MZ) co-twins of probands with schizophrenia had increased chances of mania $(8.2 \%)$ as well as schizophrenia (40.8\%), while the MZ co-twins of manic probands had an increased risk of schizophrenia $(13.6 \%)$ as well as mania $(36.4 \%)$; the MZ co-twins of schizoaffective probands had identically increased rates (26.1\%) of schizophrenia and mania (Cardno et al., 2002).

Several new reports on candidate genes implicate variations at the same loci that influence susceptibility to both schizophrenia and bipolar disorder (Craddock et al., 2006). In particular, the most convincing candidate gene for schizophrenia, NRG1 (Munafo et al., 2006; Tosato et al., 2005) has been associated with a clinical phenotype of bipolar disorder with mood-incongruent psychotic symptoms (Green et al., 2005). Moreover, there is quite impressive evidence supporting the association between DTNBP1 and schizophrenia in Caucasian, Chinese and Japanese populations (Straub et al., 2002; Schwab et al., 2003; Tang et al., 2003; Van den Oord et al., 2003; Funke et al., 2004; Numakawa et al., 2004; Williams et al., 2005; Li et al., 2005). Few studies have investigated the role of DTNBP1 in bipolar disorder (Breen et al., 2006; Kohn et al., 2004) and it was demonstrated that DTNBP1 could only be involved in cases of bipolar disorder with psychotic features (Raybould et al., 2005). These findings suggest that NRG1 and DTNBP1 may confer susceptibility to a specific clinical phenotype with combined features of psychosis and mania (Craddock et al., 2006; Ivleva et al., 2008). Similarly, it was found that variations in the most promising candidate gene for bipolar disorder, D-amino acid oxidase activator (DAOA) (DeteraWadleigh \& McMahon, 2006), may influence susceptibility to episodes of mood disorder across the traditional definitions of bipolar and schizophrenia (Owen et al., 2007).

Therefore, twin and association studies suggest that psychosis may be conceptualized as a clinical phenotype where hypothetical genes or sets of genes, interacting with environmental factors, may be responsible for vulnerability to psychosis. Depending on additional syndrome-specific genetic determinants and environmental influences, psychosis may coexist with other clinical characteristics; for example, psychosis may be present with affective symptoms or cognitive dysfunction, comprising categorical diagnoses (Ivleva et al., 2008). Similarly, it is possible that while some environmental exposures may play a role in a subgroup of people with psychosis, other forms of psychosis may be due to other risk factors such as genetic ones.

\section{DISENTANGLING THE ENVIRONMENTAL CONTRIBUTION}

If phenotypic heterogeneity has been invoked as the main reason for the inconsistencies of genetics findings in schizophrenia, another important issue is to establish the role of the environment. It is still unclear what specific roles the environment plays in the pathway which leads to the disorder. Two kinds of epidemiological findings suggest that genes and environment contribute interactively in producing psychosis: the geographic, ethnic and demographic variation in the incidence of schizophrenia (McGrath et al., 2004; Kirkbride et al., 2006) and the marked variability in an individual's response to the same environmental factor risks.

A recent population-based first-episode study conducted in the UK demonstrated considerable heterogeneity in incidence rates of schizophrenia and other psychoses in terms of sex, age, ethnic group and place of birth. This confirms that environmental effects at the individual, and perhaps neighbourhood level, may interact with genetic factors in the etiology of psychosis (Kirkbride et al., 2006). Moreover, a recent systematic review of studies published in the international literature on the epidemiology of schizophrenia over the last 40 years found a prominent variation in the incidence of schizophrenia between countries in terms of sex, age, ethnic group (McGrath, 2008). This variation is an important tool for understanding and investigating the causes of psychosis. An apparent lack of geographical variation had led to an emphasis on genetic factors, whereas heterogeneity would support environmental causes that most likely interact with the genome.

The higher or lower likelihood of developing schizophrenia in response to a given environmental insult reveals the etiological contribution of gene-environment interactions $(\mathrm{GxE})$. This model postulates that a causal role cannot be found for either genes or environment alone, but in their synergic co-participation. There are a number of environmental exposures that are associated with psychotic disorders and for which a GxE mechanism has been proposed. These include both biological factors, such as malnutrition (Penner \& Brown, 2007), obstetric complications (Cannon et al., 2002; Geddes et al., 1999), paternal age (Malaspina et al., 2001; Zammit et al., 2003), maternal infections (Brown et al., 2001) and psychosocial factors such as childhood trauma ( $\operatorname{Read}$ et al., 2005), stressful life events (Harrison, 2004), migration (Boydell et al., 2001; Cooper et al., 2008), urbanicity (Van Os et al., 2003; 2004) and cannabis use (Henquet et al., 2008). 
Notably, each of these putative causes is actually a class of potential causes. At face value, these data would seem to favour the hypothesis of etiological heterogeneity (Tsuang \& Faraone, 1995).

However, Cardno \& Farmer (1995) challenge the heterogeneity hypothesis: they argue that differences demonstrated phenotypically by multivariate statistical techniques are quantitative and only compatible with etiological homogeneity resulting from a threshold of disease burden. Variations in phenotype can be placed on this spectrum with non-paranoid, predominantly negative symptoms and/or familial forms of the disorder causing a greater impact than paranoid, predominantly positive symptoms and/or sporadic forms. The problems are complex and far from fully clarified. Perhaps the heterogeneity debate should consider the possibility of rewording the question: 'Heterogeneity: present or not?' to 'Heterogeneity: how much?'. This altered perspective opens up a range of heterogeneity models for empirical testing (Tsuang \& Faraone, 1995). In this respect, for the bulk of schizophrenic disorders, etiological heterogeneity is very likely and almost certainly is a hypothesis worth testing (Tsuang \& Faraone, 1995).

\section{LINKING GENETICS TO PSYCHOPATHOLOGY AND ENVIRONMENT}

Despite the difficulties in measuring and modelling environmental effects (Jones \& Cannon, 1998), progress in understanding the etiology of schizophrenia will depend upon the availability of good measures of genetic accountability as well as of relevant environmental exposures.

Driven by clinical observations and research needs, an approach based on phenotypic dissection has emerged to overcome the difficulties that are inherent in research into multifactorial phenotypes (Rietkerk et al., 2008). This approach deconstructs schizophrenia and bipolar disorder into phenotypes based on symptoms, and then, correlates particular phenotypes with genetic variants (Jablensky, 2006). In fact, it has been suggested that the "schizophrenia genes" do not code for schizophrenia per se but for some broader clinical construct such as psychosis (Kendler et al., 1998; Weiser et al., 2005; Craddock \& Owen, 2007). Therefore, it is necessary to consider the possibility that there may be no "one" variant of schizophrenia with a definable etiology, and to accept that there are multiple pathways towards psychosis. Perhaps, the category 'schizophrenia' may include several diseases whose clinical manifestations are similar.
The prospective of a dimensional, symptom-based approach focused on an individual and sub-syndromal phenotype is attractive because it may provide a model for studying the heterogeneity of schizophrenia, enhancing the ability to identify the underlying pathophysiology of the illness (Carpenter et al., 1993).

To date, relatively limited work has been done to identify genetic variants associated with specific clinical phenomena. Gene-symptom relationships have emerged primarily from follow-up studies of putative schizophrenia risk genes, with only handful of replicated findings (DeRosse et al., 2008). Significant relationships have been thoroughly reported between SNPs in DISC1 gene and the severity of delusions (Hennah et al., 2003; DeRosse et al., 2007) and SNPs in DTNBP1 and negative symptoms (Tosato et al., 2007; DeRosse et al., 2006a; Fanous et al., 2004). In addition, a number of studies have indicated that specific genetic variants may act to modify the clinical presentation of illness without increasing the overall risk for the illness itself. Emblematic is the example of COMT gene: although the evidence in favour of a role of the COMT Val ${ }^{158} \mathrm{Met}$ in predisposing to vulnerability to schizophrenia is still controversial (Glatt et al., 2003; Munafo et al., 2005, Allen et al., 2008), the polymorphism may be implicated in determining affective symptomatology in individuals suffering from schizophrenia (McClay et al., 2006; DeRosse et al., 2006b; Herken \& Erdal, 2001). Indeed, associations have been reported between negative symptoms and variation in BDNF and DAT1 (Fanous et al., 2004) and between positive symptoms and variations in DRD4 (Serretti et al., 2001) and in DRD2 (Serretti et al., 2000).

The direct empirical evidence for a plausible biological mechanism linking environment to schizophrenia is, so far, very limited. The most notable exceptions are a new generation of birth cohort studies which prospectively assesses the impact of a given exposure on genotype over a long period of time; a brilliant example of this approach is represented by the Dunedin birth cohort study. In one of a series of papers from these researchers, it was found that individuals who smoked cannabis before the age of 15 years and who carry the COMT Valine allele had an increased risk of developing a schizophreniform disorder. They exhibit more psychotic symptoms than individuals carrying the Methionine allele (Caspi et al., 2005). This study, notable for its longitudinal design, also documents legitimate concerns about how to accurately assess the environmental risk exposure of participants: it is in fact difficult to measure the amount of active drug that is ingested in different forms with different tetrahydrocannabinol levels during recreational cannabis use over

Epidemiologia e Psichiatria Sociale, 18, 2, 2009 
many years. In another study conducted within the framework of the Dunedin cohort it was found that individuals with one or two copies of the "short" serotonin transporter allele exhibited more depressive episodes and suicidality following adverse life events than individuals with two copies of the "long" allele (Caspi et al., 2003). This study shows how it is challenging to measure the frequency, timing and extent of the trauma caused by adverse psychosocial events whose negative effects may act cumulatively across long periods of an individual's lifetime (Van Os et al., 2008; Caspi \& Moffitt, 2006).

\section{CONCLUSION}

The difficulty in gaining a consistent and clear-cut picture of the genetics of schizophrenia mirrors the marked clinical and neurobiological heterogeneity of the disorder (Tamminga \& Holcomb, 2005). A comprehensive global model to understand clinical heterogeneity in schizophrenia is still lacking. As long as we are not able to disentangle the question of heterogeneity at the clinical level, it is not likely that heterogeneity at the etiological and pathophysiological levels will be solved. Acknowledging that schizophrenia is neither an entity nor a unity, we should analyze its psychopathology through its different elements and search for the factors which determine each of them. It can therefore be expected that research on symptoms or longitudinally consistent psychopathological dimensions is better suited for etio-pathogenetic investigations than research based on diagnoses.

It will be necessary in the future to conduct studies that define persistent aspects of the schizophrenic profile which are more likely to represent an underlying biological pathogenesis as opposed to fluctuating, possibly environmentally mediated symptoms. The definition of a particular clinical phenotype based on symptoms, social functioning and prognosis may be achieved using a multiwave longitudinal design. The correlation of genetic risk factors with this new clinical phenotype will not only permit an assessment of the clinical heterogeneity of the disease, but will also improve the classification of mental disorders, and potentially enable the identification of useful biological markers. Moreover, the identification of genetic factors will be important for clinical prognostication and planning, treatment outcome and social adaptation (Rosenman et al., 2003; Allardyce et al., 2007). The identification of genetic factors will facilitate the search for independent environmental factors and enable investigation into the mechanism of interaction between genes and the environment. Again, the cohort approach may be a helpful design because it permits the collection of prospective longitudinal histories of participants' environmental exposure, of the outcome of mental disorders and of the characterization of genotypes. In fact, sample size requirements can be reduced with high-quality measurements of environmental risk factors, especially when measurements are repeated over time (Wong et al., 2003).

In the next few years, the task of epidemiologists researching the genetics of schizophrenia will be:

1) the provision of convincing evidence that allows a better understanding of the mechanisms that underline the hypothesized GxE interactions;

2) the development of models of control factors to rule out alternative explanations, reinforcing confidence in the GxE interactions;

3) to define whether such interactions account for a nontrivial proportion of the disorder in the human population (Caspi \& Moffitt, 2006).

At the same time, progress in molecular genetics will produce a great amount of data about the genome. A multidisciplinary approach which carefully takes into account both environmental factors and genetics, and which is capable of producing hypothesis-driven research strategies on final biological pathways, may represent the most productive and fruitful approach.

\section{REFERENCES}

Alkelai A., Baum A., Carless M., Crowley J., Dasbanerjee T., Dempster E., Docherty S., Hare E., Galsworthy M.J., Grover D., Glubb D., Karlsson R., Mill J., Sen S., Quinones M.P., Vallender E.J., Verma R., Vijayan N.N., Villafuerte S., Voineskos A.N., Volk H., Yu L., Zimmermann P. \& DeLisi L.E. (2008). The XVth World Congress of Psychiatric Genetics, October 7-11, 2007: Rapporteur summaries of oral presentations. American Journal of Medical Genetics B Neuropsychiatry and Genetics 147B, 233-277.

Allardyce J., Gaebel W., Zielasek J. \& Van Os J. 2007. Deconstructing Psychosis conference February 2006: the validity of schizophrenia and alternative approaches to the classification of psychosis. Schizophrenia Bulletin 33, 863-867.

Allen N.C., Bagade S., McQueen M.B., Ioannidis J.P., Kavvoura F.K., Khoury M.J., Tanzi R.E. \& Bertram L. (2008). Systematic metaanalyses and field synopsis of genetic association studies in schizophrenia: the SzGene database. Nature Genetics 40, 827-834.

Andreasen N.C. \& Olsen S. (1982). Negative v positive schizophrenia. Definition and validation. Archives of General Psychiatry 39, 789-794.

Andreasen N.C., Nopoulos P., Schultz S., Miller D., Gupta S., Swayze V. \& Flaum M. (1994). Positive and negative symptoms of schizophrenia: past, present, and future. Acta Psychiatrica Scandinavica, Suppl 384, 51-59.

Baron M., Gruen R., Asnis L. \& Kane J. (1982). Schizoaffective illness, schizophrenia and affective disorders: morbidity risk and genetic transmission. Acta Psychiatrica Scandinavica 65, 253-262.

Bleuler E. (1911). Dementia praecox oder die Gruppe der Schizophrenien. In Handbuch der Psychiatrie (ed. G. Aschaffenburg). Deuticke: Leipzig. 
Bowie C.R., Reichenberg A., Patterson T.L., Heaton R.K. \& Harvey P.D. (2006). Determinants of real-world functional performance in schizophrenia subjects: correlations with cognition, functional capacity, and symptoms. American Journal of Psychiatry 163, 418-425.

Bowie C.R., Leung W.W., Reichenberg A., McClure M.M., Patterson T.L., Heaton R.K. \& Harvey P.D. (2008). Predicting schizophrenia patients' real-world behavior with specific neuropsychological and functional capacity measures. Biological Psychiatry 63, 505-511.

Boydell J., Van Os J., McKenzie K., Allardyce J., Goel R., McCreadie R.G. \& Murray R.M. (2001). Incidence of schizophrenia in ethnic minorities in London: ecological study into interactions with environment. British Medical Journal 323, 1336-1338.

Breen G., Prata D., Osborne S., Munro J., Sinclair M., Li T., Staddon S., Dempster D., Sainz R., Arroyo B., Kerwin R.W., St Cloud D. \& Collier D. (2006). Association of the dysbindin gene with bipolar affective disorder. American Journal of Psychiatry 163, 1636-1638.

Brown A.S., Cohen P., Harkavy-Friedman J., Babulas V., Malaspina D., Gorman J.M. \& Susser E.S. (2001). A.E. Bennett Research Award. Prenatal rubella, premorbid abnormalities, and adult schizophrenia. Biological Psychiatry 49, 473-486.

Brown A.S., Schaefer C.A., Quesenberry C.P., Jr., Liu L., Babulas V.P. \& Susser E.S. (2005). Maternal exposure to toxoplasmosis and risk of schizophrenia in adult offspring. American Journal Psychiatry 162, 767-773.

Cannon M., Jones P.B. \& Murray R.M. (2002). Obstetric complications and schizophrenia: historical and meta-analytic review. American Journal of Psychiatry 159, 1080-1092.

Cardno A.G. \& Farmer A.E. (1995). The case for or against heterogeneity in the etiology of schizophrenia. The genetic evidence. Schizophrenia Research 17, 153-159.

Cardno A.G. \& Gottesman I.I. (2000). Twin studies of schizophrenia: from bow-and-arrow concordances to star wars $\mathrm{Mx}$ and functional genomics. American Journal of Medical Genetics 97, 12-17.

Cardno A.G., Marshall E.J., Coid B., Macdonald A.M., Ribchester T.R., Davies N.J., Venturi P., Jones L.A., Lewis S.W., Sham P.C., Gottesman I.I., Farmer A.E., McGuffin P., Reveley A.M. \& Murray R.M. (1999). Heritability estimates for psychotic disorders: the Maudsley twin psychosis series. Archives of General Psychiatry 56, 162-168.

Cardno A.G., Rijsdijk F.V., Sham P.C., Murray R.M. \& McGuffin P. (2002). A twin study of genetic relationships between psychotic symptoms. American Journal of Psychiatry 159, 539-545.

Carpenter W.T., Jr., Buchanan R.W., Kirkpatrick B., Tamminga C. \& Wood F. (1993). Strong inference, theory testing, and the neuroanatomy of schizophrenia. Archives of General Psychiatry 50, 825-831.

Caspi A. \& Moffitt T.E. (2006). Gene-environment interactions in psychiatry: joining forces with neuroscience. Nature Reviews. Neuroscience 7, 583-590.

Caspi A., Moffitt T.E., Cannon M., McClay J., Murray R., Harrington H., Taylor A., Arseneault L., Williams B., Braithwaite A., Poulton R. \& Craig I.W. (2005). Moderation of the effect of adolescentonset cannabis use on adult psychosis by a functional polymorphism in the catechol-O-methyltransferase gene: longitudinal evidence of a gene X environment interaction. Biological Psychiatry 57, 1117-1127.

Caspi A., Sugden K., Moffitt T.E., Taylor A., Craig I.W., Harrington H., McClay J., Mill J., Martin J., Braithwaite A. \& Poulton R. (2003). Influence of life stress on depression: moderation by a polymorphism in the 5-HTT gene. Science 301, 386-389.

Cooper C., Morgan C., Byrne M., Dazzan P., Morgan K., Hutchinson G., Doody G.A., Harrison G., Leff J., Jones P., Ismail K., Murray R., Bebbington P. \& Fearon P. (2008). Perceptions of disadvantage, ethnicity and psychosis. British Journal of Psychiatry 192, 185-190.

Craddock N. \& Owen M.J. (2007). Rethinking psychosis: the disadvantages of a dichotomous classification now outweigh the advantages. World Psychiatry 6, 84-91.
Craddock N., O'Donovan M.C. \& Owen M.J. (2006). Genes for schizophrenia and bipolar disorder? Implications for psychiatric nosology. Schizophrenia Bulletin 32, 9-16.

Craddock N., O'Donovan M.C. \& Owen M.J. (2008). Genome-wide association studies in psychiatry: lessons from early studies of non-psychiatric and psychiatric phenotypes. Molecular Psychiatry 13, 649-653.

Crow T.J. (2008). The emperors of the schizophrenia polygene have no clothes. Psychological Medicine 38, 1681-1685.

Davidson L. \& McGlashan T.H.. (1997). The varied outcomes of schizophrenia. Canadian Journal of Psychiatry 42, 34-43.

DeRosse P., Funke B., Burdick K.E., Lencz T., Ekholm J.M., Kane JM., Kucherlapati R. \& Malhotra A.K. (2006a). Dysbindin genotype and negative symptoms in schizophrenia. American Journal of Psychiatry 163, 532-534.

Derosse P., Funke B., Burdick K.E., Lencz T., Goldberg T.E., Kane JM., Kucherlapati R. \& Malhotra A.K. (2006b). COMT genotype and manic symptoms in schizophrenia. Schizophrenia Research 87, 28-31.

DeRosse P., Hodgkinson C.A., Lencz T., Burdick K.E., Kane J.M., Goldman D. \& Malhotra A.K. (2007). Disrupted in schizophrenia 1 genotype and positive symptoms in schizophrenia. Biological Psychiatry 61, 1208-1210.

DeRosse P., Lencz T., Burdick K.E., Siris S.G., Kane J.M. \& Malhotra A.K. (2008). The genetics of symptom-based phenotypes: toward a molecular classification of schizophrenia. Schizophrenia Bulletin 34, 1047-1053.

Detera-Wadleigh S.D. \& McMahon F.J. (2006). G72/G30 in schizophrenia and bipolar disorder: review and meta-analysis. Biological Psychiatry 60, 106-114.

Dickinson D., Bellack A.S. \& Gold J.M. (2007). Social/communication skills, cognition, and vocational functioning in schizophrenia. Schizophrenia Bulletin 33, 1213-1220.

Dollfus S. \& Everitt B. (1998). Symptom structure in schizophrenia: two-, three- or four-factor models? Psychopathology 31, 120-130.

Eaton W.W., Thara R., Federman B., Melton B. \& Liang K.Y. (1995). Structure and course of positive and negative symptoms in schizophrenia. Archives of General Psychiatry 52, 127-134.

Emsley R., Chiliza B. \& Schoeman R. (2008). Predictors of longterm outcome in schizophrenia. Current Opinion in Psychiatry 21, 173-177.

Fanous A.H., Neale M.C., Straub R.E., Webb B.T., O'Neill A.F., Walsh D. \& Kendler K.S. (2004). Clinical features of psychotic disorders and polymorphisms in HT2A, DRD2, DRD4, SLC6A3 (DAT1), and BDNF: a family based association study. American Journal of Medical Genetics. Part B, Neuropsychiatric Genetics 125B, 69-78.

Fanous A.H., van den Oord E.J., Riley B.P., Aggen S.H., Neale M.C., O'Neill F.A., Walsh D. \& Kendler K.S. (2005). Relationship between a high-risk haplotype in the DTNBP1 (dysbindin) gene and clinical features of schizophrenia. American Journal of Psychiatry 162, 1824-1832.

Funke B., Finn C.T., Plocik A.M., Lake S., DeRosse P., Kane J.M., Kucherlapati R. \& Malhotra A.K. (2004). Association of the DTNBP1 locus with schizophrenia in a U.S. population. American Journal of Human Genetics 75, 891-898.

Geddes J.R., Verdoux H., Takei N., Lawrie S.M., Bovet P., Eagles J.M., Heun R., McCreadie R.G., McNeil T.F., O'Callaghan E., Stober G., Willinger U. \& Murray R.M. (1999). Schizophrenia and complications of pregnancy and labor: an individual patient data meta-analysis. Schizophrenia Bulletin 25, 413-423.

Gershon E.S., DeLisi L.E., Hamovit J., Nurnberger J.I., Jr., Maxwell M.E., Schreiber J., Dauphinais D., Dingman C.W. \& Guroff J.J. (1988). A controlled family study of chronic psychoses. Schizophrenia and schizoaffective disorder. Archives of General Psychiatry 45, 328-336.

Glatt S.J., Faraone S.V. \& Tsuang M.T. (2003). Association between a functional catechol O-methyltransferase gene polymorphism and schizophrenia: meta-analysis of case-control and family-based studies. American Journal of Psychiatry 160, 469-476. 
Green E.K., Raybould R., Macgregor S., Gordon-Smith K., Heron J., Hyde S., Grozeva D., Hamshere M., Williams N., Owen M.J., O’Donovan M.C., Jones L., Jones I., Kirov G. \& Craddock N. (2005). Operation of the schizophrenia susceptibility gene, neuregulin 1, across traditional diagnostic boundaries to increase risk for bipolar disorder. Archives of General Psychiatry 62, 642-648.

Harrison G. (2004). Trajectories of psychosis: towards a new social biology of schizophrenia. Epidemiologia e Psichiatria Sociale $13,152-157$.

Harvey PD., Koren D., Reichenberg A. \& Bowie C.R. (2006). Negative symptoms and cognitive deficits: what is the nature of their relationship? Schizophrenia Bulletin 32, 250-258.

Hegarty J.D., Baldessarini R.J., Tohen M., Waternaux C. \& Oepen G. (1994). One hundred years of schizophrenia: a meta-analysis of the outcome literature. American Journal of Psychiatry 151, 1409-1416.

Hennah W., Varilo T., Kestila M., Paunio T., Arajarvi R., Haukka J., Parker A., Martin R., Levitzky S., Partonen T., Meyer J., Lonnqvist J., Peltonen L. \& Ekelund J. (2003). Haplotype transmission analysis provides evidence of association for DISC1 to schizophrenia and suggests sex-dependent effects. Human Molecular Genetics 12, 3151-3159.

Henquet C., Di Forti M., Morrison P., Kuepper R. \& Murray R.M. (2008). Gene-environment interplay between cannabis and psychosis. Schizophrenia Bulletin 34, 1111-1121.

Herken H. \& Erdal M.E. (2001). Catechol-O-methyltransferase gene polymorphism in schizophrenia: evidence for association between symptomatology and prognosis. Psychiatric Genetics 11, 105-109.

Hijman R., Hulshoff Pol H.E., Sitskoorn M.M. \& Kahn R.S. (2003). Global intellectual impairment does not accelerate with age in patients with schizophrenia: a cross-sectional analysis. Schizophrenia Bulletin 29, 509-517.

Hyde TM., Nawroz S., Goldberg T.E., Bigelow L.B., Strong D., Ostrem J.L., Weinberger D.R. \& Kleinman J.E. (1994). Is there cognitive decline in schizophrenia? A cross-sectional study. British Journal of Psychiatry 164, 494-500.

Ivleva E., Thaker G, \& Tamminga C.A. (2008). Comparing genes and phenomenology in the major psychoses: schizophrenia and bipolar 1 disorder. Schizophrenia Bulletin 34, 734-742.

Jablensky A. (2006). Subtyping schizophrenia: implications for genetic research. Molecular Psychiatry 11, 815-836.

Jobe T.H. \& Harrow M. (2005). Long-term outcome of patients with schizophrenia: a review. Canadian Journal of Psychiatry 50, 892-900.

Jones P. \& Cannon M. (1998). The new epidemiology of schizophrenia. Psychiatric Clinics of North America 21, 1-25.

Kay S.R. \& Sevy S. (1990). Pyramidical model of schizophrenia. Schizophrenia Bulletin 16, 537-545.

Kendler KS., Karkowski L.M. \& Walsh D. (1998). The structure of psychosis: latent class analysis of probands from the Roscommon Family Study. Archives of General Psychiatry 55, 492-499.

Kennedy J.L., Farrer L.A., Andreasen N.C., Mayeux R. \& St George-Hyslop P. (2003). The genetics of adult-onset neuropsychiatric disease: complexities and conundra? Science 302, 822-826.

Kirkbride J.B., Fearon P., Morgan C., Dazzan P., Morgan K., Tarrant J., Lloyd T., Holloway J., Hutchinson G., Leff J.P., Mallett R.M., Harrison G.L., Murray R.M. \& Jones P.B. (2006). Heterogeneity in incidence rates of schizophrenia and other psychotic syndromes: findings from the 3-center AeSOP study. Archives of General Psychiatry 63, 250-258.

Kohn Y., Danilovich E., Filon D., Oppenheim A., Karni O., Kanyas K., Turetsky N., Korner M. \& Lerer B. (2004). Linkage disequlibrium in the DTNBP1 (dysbindin) gene region and on chromosome 1p36 among psychotic patients from a genetic isolate in Israel: findings from identity by descent haplotype sharing analysis. American Journal of Medical Genetics, Part B. Neuropsychiatric Genetics 128B, 65-70.

Lasalvia A., Bonetto C., Cristofalo D., Tansella M. \& Ruggeri M. (2007a). Predicting clinical and social outcome of patients attending 'real world' mental health services: a 6-year multi-wave follow-up study. Acta Psychiatrica Scandinavica, Suppl. 437, 16-30.
Lasalvia A., Bonetto C., Salvi G., Bissoli S., Tansella M. \& Ruggeri M. (2007b). Predictors of changes in needs for care in patients receiving community psychiatric treatment: a 4-year follow-up study. Acta Psychiatrica Scandinavica, Suppl. 437, 31-41.

Lenzenweger M.F., Dworkin R.H. \& Wethington E. (1991). Examining the underlying structure of schizophrenic phenomenology: evidence for a three-process model. Schizophrenia Bulletin 17, 515-524.

Li T., Zhang F., Liu X., Sun X., Sham PC., Crombie C., Ma X., Wang Q., Meng H., Deng W., Yates P., Hu X., Walker N., Murray R.M., St Cloud D. \& Collier D.A. (2005). Identifying potential risk haplotypes for schizophrenia at the DTNBP1 locus in Han Chinese and Scottish populations. Molecular Psychiatry 10, 1037-1044.

Liddle P.F. (1987). The symptoms of chronic schizophrenia. A reexamination of the positive-negative dichotomy. British Journal of Psychiatry 151, 145-151.

Lindenmayer J.P., Bernstein-Hyman R. \& Grochowski S. (1994). Five-factor model of schizophrenia. Initial validation. Journal of Nervous and Mental Disease 182, 631-638.

Lysaker P. \& Bell M. (1995). Negative symptoms and vocational impairment in schizophrenia: repeated measurements of work performance over six months. Acta Psychiatrica Scandinavica 91, 205-208.

Maier W., Lichtermann D., Minges J., Hallmayer J., Heun R., Benkert O. \& Levinson D.F. (1993). Continuity and discontinuity of affective disorders and schizophrenia. Results of a controlled family study. Archives of General Psychiatry 50, 871-883.

Maier W., Hofgen B., Zobel A. \& Rietschel M. (2005). Genetic models of schizophrenia and bipolar disorder: overlapping inheritance or discrete genotypes? European Archives of Psychiatry and Clinical Neuroscience 255, 159-166.

Malaspina D., Harlap S., Fennig S., Heiman D., Nahon D., Feldman D. \& Susser E.S. (2001). Advancing paternal age and the risk of schizophrenia. Archives of General Psychiatry 58, 361-367.

Malla AK., Norman R.M., Williamson P., Cortese L. \& Diaz F. (1993). Three syndrome concept of schizophrenia. A factor analytic study. Schizophrenia Research 10, 143-150.

McClay J.L., Fanous A., van den Oord E.J., Webb B.T., Walsh D., O'Neill F.A., Kendler K.S. \& Chen X. (2006). Catechol-Omethyltransferase and the clinical features of psychosis. American Journal of Medical Genetics, Part B. Neuropsychiatric Genetics 141B, 935-938.

McGrath J. (2008). Hypotheses desert us, while data defend us. Schizophrenia Research 102, 27-28.

McGrath J., Saha S., Welham J., El Saadi O., MacCauley C. \& Chant D. (2004). A systematic review of the incidence of schizophrenia: the distribution of rates and the influence of sex, urbanicity, migrant status and methodology. BMC Medicine 2, 13.

Meehl P.E. (1995). Bootstraps taxometrics. Solving the classification problem in psychopathology. American Psychology 50, 266-275.

Mockler D., Riordan J. \& Sharma T. (1997). Memory and intellectual deficits do not decline with age in schizophrenia. Schizophrenia Research 26, 1-7.

Mortensen PB., Pedersen C.B., Melbye M., Mors O. \& Ewald H. (2003). Individual and familial risk factors for bipolar affective disorders in Denmark. Archives of General Psychiatry 60, 1209-1215.

Munafo M.R., Bowes L., Clark T.G. \& Flint J. (2005). Lack of association of the COMT (Val158/108 Met) gene and schizophrenia: a meta-analysis of case-control studies. Molecular Psychiatry 10, 765-770.

Munafo M.R., Thiselton D.L., Clark T.G. \& Flint J. (2006). Association of the NRG1 gene and schizophrenia: a meta-analysis. Molecular Psychiatry 11, 539-546.

Murray RM., Sham P., Van Os J., Zanelli J., Cannon M. \& McDonald C. (2004). A developmental model for similarities and dissimilarities between schizophrenia and bipolar disorder. Schizophrenia Research 71, 405-416. 
Norton N. Williams H.J. \& Owen M.J. (2006). An update on the genetics of schizophrenia. Current Opinion in Psychiatry 19, 158-164.

Numakawa T., Yagasaki Y., Ishimoto T., Okada T., Suzuki T., Iwata N., Ozaki N., Taguchi T., Tatsumi M., Kamijima K., Straub R.E., Weinberger D.R., Kunugi H. \& Hashimoto R. (2004). Evidence of novel neuronal functions of dysbindin. a susceptibility gene for schizophrenia. Human Molecular Genetics 13, 2699-2708.

Owen M.J., Craddock N. \& Jablensky A. (2007). The genetic deconstruction of psychosis. Schizophrenia Bulletin 33, 905-911.

Penner J.D. \& Brown A.S. (2007). Prenatal infectious and nutritional factors and risk of adult schizophrenia. Expert Review on Neurotherapeutics 7, 797-805.

Peralta V. \& Cuesta M.J. (2000). Clinical models of schizophrenia: a critical approach to competing conceptions. Psychopathology 33, 252-258.

Peralta V. \& Cuesta M.J. (2003). The diagnosis of schizophrenia: old wine in new bottles. International Journal of Psychology and Psychological Therapy 3, 141-152.

Peralta V., Cuesta M.J. \& de Leon J. (1994). An empirical analysis of latent structures underlying schizophrenic symptoms: a four-syndrome model. Biological Psychiatry 36, 726-736.

Raybould R., Green E.K., MacGregor S., Gordon-Smith K., Heron J., Hyde S., Caesar S., Nikolov I., Williams N., Jones L., O'Donovan M.C., Owen M.J., Jones I., Kirov G. \& Craddock N. (2005). Bipolar disorder and polymorphisms in the dysbindin gene (DTNBP1). Biological Psychiatry 57, 696-701.

Read J., Van Os J., Morrison A.P. \& Ross C.A. (2005). Childhood trauma, psychosis and schizophrenia: a literature review with theoretical and clinical implications. Acta Psychiatrica Scandinavica 112, 330-350.

Rietkerk T., Boks M.P., Sommer I.E., Liddle P.F., Ophoff R.A. \& Kahn R.S. (2008). The genetics of symptom dimensions of schizophrenia: review and meta-analysis. Schizophrenia Research 102, 197-205.

Rosenman S., Korten A., Medway J. \& Evans M. (2003). Dimensional vs. categorical diagnosis in psychosis. Acta Psychiatrica Scandinavica 107, 378-384

Ruggeri M., Lasalvia A., Tansella M., Bonetto C., Abate M., Thornicroft G., Allevi L. \& Ognibene P. (2004). Heterogeneity of outcomes in schizophrenia. 3-year follow-up of treated prevalent cases. British Journal of Psychiatry 184, 48-57.

Ruggeri M., Nosè M., Bonetto C., Cristofalo D., Lasalvia A., Salvi G., Stefani B., Malchiodi F. \& Tansella M. (2005). Changes and predictors of change in objective and subjective quality of life: multiwave follow-up study in community psychiatric practice. British Journal of Psychiatry 187, 121-130.

Sanders A.R., Duan J., Levinson D.F., Shi J., He D., Hou C., Burrell G.J., Rice J.P., Nertney D.A., Olincy A., Rozic P., Vinogradov S., Buccola N.G., Mowry B.J., Freedman R., Amin F., Black D.W., Silverman J.M., Byerley W.F., Crowe R.R., Cloninger C.R., Martinez M. \& Gejman P.V. (2008). No significant association of 14 candidate genes with schizophrenia in a large European ancestry sample: implications for psychiatric genetics. American Journal of Psychiatry 165, 497-506.

Schwab S.G., Knapp M., Mondabon S., Hallmayer J., BorrmannHassenbach M., Albus M., Lerer B., Rietschel M., Trixler M., Maier W. \& Wildenauer D.B. (2003). Support for association of schizophrenia with genetic variation in the 6p22.3 gene, dysbindin, in sib-pair families with linkage and in an additional sample of triad families. American Journal of Human Genetics 72, 185-190.

Serretti A., Lattuada E., Lorenzi C., Lilli R. \& Smeraldi E. (2000). Dopamine receptor D2 Ser/Cys 311 variant is associated with delusion and disorganization symptomatology in major psychoses. Molecular Psychiatry 5, 270-274.

Serretti A., Lilli R., Lorenzi C., Lattuada E. \& Smeraldi E. (2001). DRD4 exon 3 variants associated with delusional symptomatology in major psychoses: a study on 2,011 affected subjects. American Journal of Human Genetics 105, 283-290.
Shenton M.E., Dickey C.C., Frumin M. \& McCarley R.W. (2001). A review of MRI findings in schizophrenia. Schizophrenia Research 49, 1-52.

St Clair D. (2009). Copy number variation and schizophrenia. Schizophrenia Bulletin 35, 9-12.

Stefansson H., Rujescu D., Cichon S., Pietilainen O.P., Ingason A., Steinberg S., Fossdal R., Sigurdsson E., Sigmundsson T., BuizerVoskamp J.E., Hansen T., Jakobsen K.D., Muglia P., Francks C., Matthews P.M., Gylfason A., Halldorsson B.V., Gudbjartsson D., Thorgeirsson T.E., Sigurdsson A., Jonasdottir A., Jonasdottir A., Bjornsson A., Mattiasdottir S., Blondal T., Haraldsson M., Magnusdottir B.B., Giegling I., Moller H.J., Hartmann A., Shianna K.V., Ge D., Need A.C., Crombie C., Fraser G., Walker N., Lonnqvist J., Suvisaari J., Tuulio-Henriksson A., Paunio T., Toulopoulou T., Bramon E., Di Forti M., Murray R., Ruggeri M., Vassos E., Tosato S., Walshe M., Li T., Vasilescu C., Muhleisen T.W., Wang A.G., Ullum H., Djurovic S., Melle I., Olesen J., Kiemeney LA., Franke B., Sabatti C., Freimer N.B., Gulcher J.R., Thorsteinsdottir U., Kong A., Andreassen O.A., Ophoff R.A., Georgi A., Rietschel M., Werge T., Petursson H., Goldstein D.B., Nothen M.M., Peltonen L., Collier D.A., St Cloud D. \& Stefansson K. (2008). Large recurrent microdeletions associated with schizophrenia. Nature 455, 232-236.

Straub R.E., Jiang Y., MacLean C.J., Ma Y., Webb B.T., Myakishev M.V., Harris-Kerr C., Wormley B., Sadek H., Kadambi B., Cesare A.J., Gibberman A., Wang X., O'Neill F.A., Walsh D. \& Kendler K.S. (2002). Genetic variation in the 6p22.3 gene DTNBP1, the human ortholog of the mouse dysbindin gene, is associated with schizophrenia. American Journal of Human Genetics 71, 337-348.

Strauss J.S. \& Carpenter W.T, Jr. (1977). Prediction of outcome in schizophrenia. III. Five-year outcome and its predictors. Archives of General Psychiatry 34, 159-163.

Strauss J.S., Carpenter W.T., Jr. \& Bartko J.J. (1974). The diagnosis and understanding of schizophrenia. Part III. Speculations on the processes that underlie schizophrenic symptoms and signs. Schizophrenia Bulletin 11, 61-69.

Sullivan P.F. (2008). The dice are rolling for schizophrenia genetics. Psychological Medicine 38, 1693-1696.

Sullivan P.F., Kendler K.S. \& Neale M.C. (2003). Schizophrenia as a complex trait: evidence from a meta-analysis of twin studies. Archives of General Psychiatry 60, 1187-1192.

Tamminga C.A. \& Holcomb H.H. (2005). Phenotype of schizophrenia: a review and formulation. Molecular Psychiatry 10, 27-39.

Tang J.X., Zhou J., Fan J.B., Li X.W., Shi Y.Y., Gu N.F., Feng G.Y., Xing Y.L., Shi J.G. \& He L. (2003). Family-based association study of DTNBP1 in 6p22.3 and schizophrenia. Molecular Psychiatry $8,717-718$

Tosato S., Dazzan P. \& Collier D. (2005). Association between the neuregulin 1 gene and schizophrenia: a systematic review. Schizophrenia Bulletin 31, 613-617.

Tosato S., Ruggeri M., Bonetto C., Bertani M., Marrella G., Lasalvia A., Cristofalo D., Aprili G., Tansella M., Dazzan P., Diforti M., Murray R.M. \& Collier D.A. (2007). Association study of dysbindin gene with clinical and outcome measures in a representative cohort of Italian schizophrenic patients. American Journal of Medical Genetics, Part B. Neuropsychiatric Genetics 144B, 647-659.

Tsuang M.T. \& Faraone S.V. (1995). The case for heterogeneity in the etiology of schizophrenia. Schizophrenia Research 17, 161-175.

van den Oord E.J., Sullivan P.F., Jiang Y., Walsh D., O'Neill F.A., Kendler K.S. \& Riley B.P. (2003). Identification of a high-risk haplotype for the dystrobrevin binding protein 1 (DTNBP1) gene in the Irish study of high-density schizophrenia families. Molecular Psychiatry 8, 499-510.

Van Os J., Hanssen M., Bak M., Bijl R.V. \& Vollebergh W. (2003). Do urbanicity and familial liability coparticipate in causing psychosis? American Journal of Psychiatry 160, 477-482.

Van Os J., Pedersen C.B. \& Mortensen P.B. (2004). Confirmation of synergy between urbanicity and familial liability in the causation of psychosis. American Journal of Psychiatry 161, 2312-2314. 
Van Os J., Rutten B.P. \& Poulton R. (2008). Gene-environment interactions in schizophrenia: review of epidemiological findings and future directions. Schizophrenia Bulletin 34, 1066-1082.

Walsh T., McClellan J.M., McCarthy S.E., Addington A.M., Pierce S.B., Cooper G.M., Nord A.S., Kusenda M., Malhotra D., Bhandari A., Stray S.M., Rippey C.F., Roccanova P., Makarov V., Lakshmi B., Findling R.L., Sikich L., Stromberg T., Merriman B., Gogtay N., Butler P., Eckstrand K., Noory L., Gochman P., Long R., Chen Z., Davis S., Baker C., Eichler E.E., Meltzer P.S., Nelson S.F., Singleton A.B., Lee M.K., Rapoport J.L., King M.C. \& Sebat J. (2008). Rare structural variants disrupt multiple genes in neurodevelopmental pathways in schizophrenia. Science 320, 539-543.

Welcome Trust Case Control Consortium (2007). Genome-wide association study of 14,000 cases of seven common diseases and 3,000 shared controls. Nature 447, 661-678.

Weiser M., Van Os J. \& Davidson M. (2005). Time for a shift in focus in schizophrenia: from narrow phenotypes to broad endophenotypes. British Journal of Psychiatry 187, 203-205.
Weiss L.A., Shen Y., Korn J.M., Arking D.E., Miller D.T., Fossdal R., Saemundsen E., Stefansson H., Ferreira M.A., Green T., Platt O.S., Ruderfer D.M., Walsh C.A., Altshuler D., Chakravarti A., Tanzi R.E., Stefansson K., Santangelo S.L., Gusella J.F., Sklar P., Wu B.L. \& Daly M.J. (2008). Association between microdeletion and microduplication at 16p11.2 and autism. New England Journal of Medicine 358, 667-675.

Williams N.M., O’Donovan M.C. \& Owen M.J. (2005). Is the dysbindin gene (DTNBP1) a susceptibility gene for schizophrenia? Schizophrenia Bulletin 31, 800-805.

Wong M.Y., Day N.E., Luan J.A., Chan K.P. \& Wareham N.J. (2003). The detection of gene-environment interaction for continuous traits: should we deal with measurement error by bigger studies or better measurement? International Journal of Epidemiology 32, 51-57.

Zammit S., Allebeck P., Dalman C., Lundberg I., Hemmingson T., Owen M.J. \& Lewis G. (2003). Paternal age and risk for schizophrenia. British Journal of Psychiatry 183, 405-408. 